\title{
PENDIDIKAN KARAKTER PRESPEKTIF PENDIDIKAN ISLAM DALAM UPAYA DERADIKALISASI PAHAM RADIKAL
}

\author{
Irwan Fathurrochman \\ Sekolah Tinggi Agama Islam Negeri (STAIN) Curup Indonesia \\ Email:inhamna@gmail.com
}

\section{Eka Apriani}

Sekolah Tinggi Agama Islam Negeri (STAIN) Curup Indonesia

Email: ekaapriani_90@ymail.com

\begin{abstract}
The basis of character education in Islamic education is derived from the word akhlaq in plural form of khuluq which according to language is interpreted character, behavior, behavior or character. Essentially, character in education is the spirit in the Islamic education. Islamic education and character in education create students with better characters and values. It is clear that Islamic education with detailed guidance will never leave the content of al-Qur'an and al-Sunnah that in line with the character in education, in example building the students with good moral. There are seven characters that should be had by students namely emphaty, conscience, self control, respect, kidness, tolerance, and justice. The success of Islamic education does not depend on one component only but also all of education components.
\end{abstract}

Keywords: Characters Education, Islamic Education, Radicalsm

\section{A. Pendahuluan}

Pendidikan di Indonesia hingga sekarang masih menyisakan banyak persoalan, baik dari segi kurikulum, manajemen, maupun para pelaku dan pengguna pendidikan. sumber daya manusia Indonesia masih belum mencerminkan cita-cita pendidikan yang diharapkan. Masih banyak ditemukan kasus-kasus seperti siswa melakukan kecurangan ketika sedang menghadapi ujian, bersikap malas dan senang bermain dan hura-hura, senang tawuran antar sesama siswa, melakukan pergaulan bebas, hingga terlibat narkoba dan tindak kriminal lainnya. Di sisi lain, masih ditemukan pula guru yang melakukan kecurangan-kecurangan dalam sertifikasi dan dalam penyelenggaraan Ujian Nasional (UN). 
Atas dasar inilah, maka pendidikan kita perlu ditinjau ulang agar dapat menghasilkan lulusan yang lebih berkualitas dan siap menghadapi "dunia" masa depan yang penuh dengan problema dan tantangan serta dapat menghasilkan lulusan yang memiliki karakter mulia, yakni: memiliki kepandaian sekaligus kecerdasan, memiliki kreativitas tinggi sekaligus sopan dan santun dalam berkomunikasi, serta memiliki kejujuran dan kedisiplinan sekaligus memiliki tanggung jawab yang tinggi. Dengan kata lain, pendidikan harus mampu mengemban misi pembentukan karakter (character building) sehingga para peserta didik dan para lulusannya dapat berpartisipasi dalam mengisi pembangunan dengan baik dan berhasil tanpa meninggalkan nilai-nilai karakter mulia.

Pendidikan Karakter atau pendidikan watak sejak awal munculnya dalam pendidikan sudah dianggap sebagai hal yang niscaya oleh para ahli. John Dewey misalnya, sebagaimana dikutip oleh Frank G. Goble pada tahun 1916, pernah berkata, "sudah merupakan hal lumrah dalam teori pendidikan bahwa pembentukan watak merupakan tujuan umum pengajaran dan pendidikan budi pekerti di sekolah."1 Di Indonesia sendiri pendidikan karakter dicanangkan oleh pemerintah Susilo Bambang Yudhoyono (SBY) dalam peringatan Hari Pendidikan Nasional pada 2 Mei 2010. Pendidikan karakter menjadi isu yang sangat hangat saat itu, sehingga pemerintah memiliki tekad untuk menjadikan pengembangan karakter dan budaya bangsa sebagai bagian yang tak terpisahkan dari sistem pendidikan nasional yang harus didukung secara serius. $^{2}$ Dengan demikian, semua lembaga pendidikan di negara ini wajib mendukung kebijakan Presiden tersebut.

\section{B. Terminologi Pendidikan Karakter}

Tentang kata karakter, dapat dilihat dari dua sisi yakni sisi kebahasaan dan sisi istilah. Menurut bahasa (etimologi) kata karakter berasal dari Bahasa Latin Kharakter, kharassein, dan kharax. Dalam bahasa Yunani character berasal dari atau charassein, yang berarti "membuat tajam" dan "membuat dalam." Dalam bahasa Inggris disebut character dan dalam bahasa Indonesia menjadi kata karakter. Menurut Kamus Besar Bahasa Indonesia, karakter diartikan sebagai tabiat, watak, sifat-sifat kejiwaan, akhlak

${ }^{1}$ F. Mu'in, Pendidikan Karakter Konstruksi Teoritik dan Praktik, Yogyakarta: Ar-Ruzz Media, 2011), h. 297

${ }^{2}$ Ibid., h. 323 
atau budi pekerti yang membedakan seseorang dengan yang lain. Karakter dapat diartikan sebagai tabiat perangai atau perbuatan yang selalu dilakukan (kebiasaan). Karakter dapat dimaknai bahwa keadaan asli yang ada dalam diri individu seseorang. Karakter adalah watak, sifat atau hal-hal yang memang sangat mendasar pada diri seseorang, hal-hal yang sangat abstrak pada diri seseorang, dan sering orang menyebutnya dengan tabiat atau perangai.

Dengan demikian karakter yang akan dibahas dalam artikel ini mengacu kepada pemahaman "akhlak" yang memiliki penjelasan sebagaimana berikut ini, menurut etimologi Arab, akhlak adalah bentuk jam' (plural) dari “khuluq" yang merupakan bentuk masdar (infinitif) dari kata khalaqa - yakhluqu - khuluqan yang memiliki arti perangai (as-sajiyah), kelakuan, tabiat atau watak dasar (al-thabi'ah); kebiasaan atau kelaziman (al-'adat), peradaban yang baik (al-muru'ah), dan agama (al-din). Dalam Kamus Besar Bahasa Indonesia, kata "akhlak" diartikan sebagai budi pekerti atau kelakuan. Selanjutnya Mahmud merujuk pendapat al-Ghazali, mengatakan dari sisi bahasa kata al-khalaq (fisik) dan al-khuluq (akhlak) adalah dua kata yang sering dipakai secara bersamaan. Karena manusia terdiri dari dua unsur fisik dan non-fisik. Unsur fisik dapat dilihat oleh mata kepala. Sedangkan unsur non fisik dapat dilihat oleh mata batin. Menurut Shihab walaupun kata "akhlak" memiliki makna tabiat, perangai, kebiasaan, bahkan, agama tetapi tidak ditemukan dalam al-Qur'an, yang ditemukan hanyalah bentuk tunggal dari kata itu yaitu khuluq. ${ }^{3}$ Hanya saja kata akhlak banyak ditemukan dalam hadis seperti dalam salah satu hadis Nabi yang sangat populer yang artinya: "Sesungguhnya aku diutus untuk menyempurnakan akhlak mulia" (HR. Malik). Adapun perkataan akhlak bersumber dari kalimat yang tercantum dalam al-Qur`an surat alQalam ayat 4:

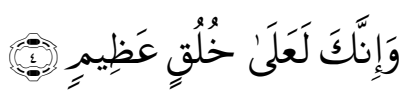

"Dan Sesungguhnya kamu benar-benar berbudi pekerti yang agung."

Selanjutnya, akhlak dalam perspektif Islam, akhlak terkait erat dengan ajaran dan sumber Islam tersebut yaitu wahyu. Sikap dan penilaian akhlak selalu dihubungkan dengan ketentuan syari'ah dan aturannya. Dalam Islam, ada beberapa keistimewaan

${ }^{3}$ M. Quraish Shihab, Tafsir Al-Mishbah: Pesan, Kesan dan Keserasian Al-Qur`an, Volume 13, (Jakarta: Lentera Hati, 2002), h. 56 
akhlak yang menjadi karekteristik, salah satunya menurut Jauhari, guru besar Akidah Filsafat di Universitas al-Azhar Kairo, yang dikutip di dalam Syarif, menjelaskan beberapa karakteristik akhlak, di antaranya: ${ }^{4}$

1. Bersifat universal.

2. Logis, menyentuh perasaan hati nurani.

3. Memiliki demensi tanggung jawab, baik pada sektor pribadi ataupun masyarakat.

4. Tolak ukur tidak saja ditentukan dengan realita perbuatan tapi juga di lihat dari segi motif perbuatan.

5. Dalam pengawasan pelaksanaan akhlak Islami ditumbuhkan kesadaran bahwa yang mengawasi adalah Allah SWT.

6. Akhlak Islami selalu memandang manusia sebagai insan yang terdiri dari aspek jasmani dan rohani yang harus dibangun secara seimbang.

7. Kebaikan yang ditawarkan akhlak Islam adalah untuk kebaikan manusia, mencakup tiap ruang dan waktu.

8. Akhlak Islam selalu memberikan penghargaan di dunia maupun di akhirat bagi setiap kebaikan, demikian pula setiap keburukan diberi sanksi atau hukuman.

Dengan konsep akhlak ini, manusia diajarkan untuk selalu berbuat baik dan mencegah perbuatan yang tidak baik dalam hubungannya dengan Tuhannya, manusia dan makhluk lainnya. Konsep ini berhubungan dengan sistem nilai yang mengatur pola sikap dan tindakan manusia di dunia. Sistem nilai yang dimaksud adalah ajaran Islam yang berpedoman kepada al-Qur`an dan Sunnah Rasulullah SAW. sebagai sumber utama. Akhlak terbagi menjadi dua bagian. Pertama, akhlak baik yang dinamakan akhlaq mahmudah (akhlak terpuji), akhlaq al-karimah (akhlak mulia) adalah akhlak yang baik dan benar menurut syari'at Islam. Kedua, akhlaq madzmumah adalah akhlak tercela dan tidak benar menurut syari'at Islam.

Dilihat dari ruang lingkupnya, akhlak Islam dibagi menjadi dua bagian, yaitu akhlak terhadap Khaliq (Allah Swt.) dan akhlak terhadap makhluq (ciptaan Allah). Akhlak terhadap makhluk masih dirinci lagi menjadi beberapa macam, seperti akhlak terhadap sesama manusia, akhlak terhadap makhluk hidup selain manusia (seperti tumbuhan dan binatang), serta akhlak terhadap benda mati. Berdasarkan penjelasan dan 2012), h. 7

${ }^{4}$ Ulil Amri Syarif, Pendidikan Karakter Berbasis al-Qur`an, (Jakarta: RajaGrafindo Press, 
definisi akhlak di atas menurut filusuf dan ajaran Islam, dapat disimpulkan bahwa akhlak adalah segala sesuatu yang telah tertanam kuat atau terparti dalam diri seseorang, yang akan melahirkan perbuatan-perbuatan yang tanpa melalui pemikiran atau perenungan terlebih dahulu. Artinya bahwa perbuatan itu dilakukan dengan reflek dan spontan tanpa difikirkan terlebih dahulu. Jika sifat yang tertanam itu darinya muncul perbuatan- perbuatan terpuji - menurut rasio dan syari'at - maka sifat tersebut dinamakan akhlak yang baik. Sedangkan jika terlahir perbuatan-perbuatan buruk maka sifat tersebut dinamakan dengan akhlak buruk.

Pada hakikatnya khuluq (budi pekerti) atau akhlaq merupakan suatu kondisi atau sifat yang telah meresap ke dalam jiwa dan menjadi kepribadian seseorang. Kemudian timbul berbagai macam kegiatan secara spontan dan mudah tanpa dibuat-buat, tanpa memerlukan pertimbangan dan pemikiran. Hal ini sesuai dengan al-Qur`an Surat alSyams ayat 8-10 yang mengungkapkan kecenderungan potensi baik dan buruk yang dimiliki manusia.

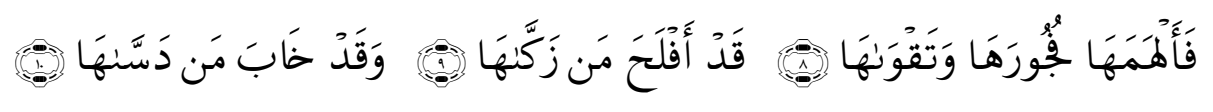

"Maka Allah mengilhamkan kepada jiwa itu (jalan) kefasikan dan ketakwaannya (8).Sesungguhnya beruntunglah orang yang mensucikan jiwa itu (9) dan Sesungguhnya merugilah orang yang mengotorinya (10)."

Selanjutnya, menurut Elkind dan Sweet pendidikan karakter adalah usaha sengaja untuk menolong orang agar memahami, peduli dan bertindak atas dasar nilainilai etis. ${ }^{5}$ Di mana tatkala kita berfikir tentang bentuk karakter yang ingin ditunjukkan oleh anak-anak, teramat jelas bahwa kita menghendaki mereka mampu menilai apa yang benar, peduli tentang apa yang benar, serta melakukan apa yang diyakini benar, bahkan ketika menghadapi tekanan dari luar dan godaan dari dalam. Adapun pendidikan karakter menurut Megawangi adalah sebuah usaha untuk mendidik anak-anak agar dapat mengambil keputusan dengan bijak dan mempraktikkannya dalam kehidupan sehari-hari, sehingga mereka dapat memberikan kontribusi positif kepada lingkungannya. ${ }^{6}$

\footnotetext{
${ }^{5}$ D. H. Elkind \& F. Sweet, (2004), You Are A Character Educator, diambil Dari http://www.goodcharacter.com/Article_4.html, pada tanggal 01 Januari 2017 pukul 12.00.

${ }^{6}$ Ratna Megawangi, Pendidikan Karakter Solusi yang Tepat untuk Membangun Bangsa, (Bogor : Indonesia Heritage Foundation, 2004), h. 24
} 
Zuhriyah mengatakan bahwa pendidikan karakter sama dengan pendidikan budi pekerti (akhlak). Tujuan budi pekerti (akhlak) adalah untuk mengembangkan watak atau tabi'at siswa dengan cara menghayati nilai-nilai keyakinan masyarakat sebagai kekuatan moral hidupnya melalui kejujuran, dapat dipercaya, dan kerjasama yang menekankan ranah efektif (perasaan, sikap) tanpa meninggalkan ranah kognitif (berfikir rasional) dan ranah psikomotorik (keterampilan, terampil mengolah data, mengemukakan pendapat dan kerjasama). Dan seseorang dapat dikatakan berkarakter atau berwatak jika telah berhasil menyerap nilai dan keyakinan yang dikehendaki masyarakat serta digunakan sebagai kekuatan dalam hidupnya. ${ }^{7}$

Istilah karakter dipakai secara khusus dalam konteks pendidikan baru muncul pada akhir abad-18, dan untuk pertama kalinya dicetuskan oleh pedadogis Jerman F.W. Foerster. $^{8}$ Terminologi ini mengacu pada pendekatan idealis-spiritualis dalam pendidikan yang juga dikenal dengan teori normatif yang menjadi prioritas adalah nilainilai transenden yang dipercaya sebagai motor penggerak sejarah, baik bagi individu maupun bagi sebuah perubahan sosial. Dalam perkembangannya, sejak tahun 1990-an, terminologi pendidikan karakter mulai ramai dibicarakan. Lickona dianggap sebagai penggusungnya melalui karyanya yang sangat memukau, The Return of Character Education sebuah buku yang menyandarkan dunia barat secara khusus dimana tempat Lickona hidup, dan seluruh dunia pendidikan secara umum, bahwa pendidikan karakter adalah sebuah keharusan. ${ }^{9}$ Inilah awal pendidikan karakter. Dapat disimpulkan bahwa pendidikan membangun karakter, secara implisit mengandung arti membangun sifat atau pola perilaku yang didasari atau berkaitan dengan nilai-nilai yang berhubungan dengan Tuhan Yang Maha Esa, diri sendiri, sesama manusia, lingkungan yang terwujud dalam pikiran, sikap, perkataan, perasaan, dan perbuatan berdasarkan norma-norma agama, hukum, tata karma, budaya, dan adat istiadat.

Selanjutnya, pendidikan akhlak sebagaimana yang telah dijelaskan oleh tokohtokoh pendidikan Islam, dapat disimpulkan bahwa pendidikan akhlak adalah usaha sadar dan tidak sadar yang dilakukan oleh seorang pendidik untuk membentuk tabiat

\footnotetext{
${ }^{7}$ Heni Zuhriyah, Pendidikan Karakter (Studi Perbandingan Antara Konsep Doni Koesoema dan Ibnu Miskawaih), (Surabaya: IAIN Sunan Ampel, 2010), h. 37

${ }^{8}$ Mansur Muslich, Pendidikan Karakter Menjawab Tantangan Krisis, (Jakarta: Bumi Aksara. 2011), h. 164

${ }^{9}$ Thomas Lickona, Educating for Character: How Our School Can Teach Respect and Responsibili, (New York, Toronto, London, Sydney, Aucland: Bantam Books., 1991), h. 93
} 
yang baik pada seorang anak didik, sehingga terbentuk manusia yang taat kepada Allah. Pembentukan tabiat ini dilakukan oleh pendidik secara continue (berkesinambungan) dengan tidak ada paksaan dari pihak manapun. Berbasis telaah teoritis dari para ahli, pendidikan akhlak dapat dikatakan sebagai pendidikan moral dalam diskursus Pendidikan Islam. Dari telaah konsep akhlak yang telah dirumuskan oleh para tokoh Pendidikan Islam masa lalu, menunjukkan bahwa tujuan puncak pendidikan akhlak adalah terbentuknya Insan Kamil.

Akhirnya dapat ditegaskan bahwa pendidikan akhlak dan pendidikan karakter, memiliki maksud dan tujuan yang semakna dan sejalan, yakni merupakan sebuah usaha sadar untuk membantu individu mempunyai kehendak untuk berbuat sesuai dengan nilai dan norma serta membiasakan perbuatan tersebut dalam kehidupannya. Pendidikan akhlak bersumber pada al-Qur`an dan Hadis, sedangkan pendidikan karakter bersumber pada nilai-nilai kebaikan yang universal. Pendidikan akhlak terkesan timur dan Islam sedangkan pendidikan karakter terkesan barat dan sekuler, dan perbedaan ini bukan alasan untuk dipertentangkan. Karena pada kenyataannya keduanya memiliki ruang untuk saling mengisi. Bahkan Thomas Lickona sebagai bapak pendidikan karakter di Amerika justru mengisyaratkan keterkaitan erat antara karakter dengan spiritualitas.

Dengan demikian, bila sejauh ini pendidikan karakter telah berhasil dirumuskan oleh para penggiatnya sampai pada tahapan yang sangat operasional meliputi metode, strategi, dan tehnik, sedangkan pendidikan akhlak sarat dengan informasi kriteria ideal dan sumber karakter baik, maka memadukan keduanya menjadi suatu tawaran yang sangat inspiratif. Hal ini sekaligus menjadi entry point bahwa pendidikan karakter memiliki ikatan yang kuat dengan nilai-nilai spiritualitas agama.

\section{Pendidikan Karakter dalam Perspektif Islam}

Manusia adalah makhluk Allah. Manusia dan alam semesta bukan terjadi sendirinya, tetapi dijadikan oleh Allah. Manusia diciptakan oleh Allah sebagai penerima dan pelaksana ajaran. Oleh karena itu, manusia ditempatkan pada kedudukan mulia. Manusia adalah makhluk pedagogik yaitu makhluk Allah yang dilahirkan membawa potensi dapat dididik dan dapat mendidik. Manusia memiliki potensi dapat didik dan mendidik sehingga mampu menjadi khalifah di bumi, pendukung dan pengembang kebudayaan. Manusia dilengkapi dengan fitrah Allah, berupa bentuk atau wadah yang 
dapat diisi dengan berbagai kecakapan dan keterampilan yang dapat berkembang, sesuai dengan kedudukannya sebagai makhluk mulia. Pikiran, perasaan dan kemampuannya berbuat merupakan komponen dari fitrah itu. Itulah fitrah Allah yang melengkapi penciptaan manusia. Oleh karena itu, demi terlaksananya pencapaian kemuliaan tersebut maka manusia harus tunduk dan patuh dengan penuh tanggung jawab untuk merealisasikan kehendak Allah yang telah diamanahkannya menjadi khalifah. Untuk mencapai tujuan tersebut, manusia membutuhkan pendidikan karena manusia adalah makhluk pedagogik.

Di kalangan umat Islam, istilah populer yang digunakan dalam pendidikan adalah al-tarbiyah. Dengan demikian, secara populer istilah tarbiyah digunakan untuk menyatakan usaha pendidikan dalam membimbing dan mengembangkan subyek didik agar benar-benar menjadi makhluk yang beragama dan berbudaya. Pertumbuhan dan perkembangan subyek didik perlu diupayakan mencapai kesempurnaannya. Oleh sebab itu, agar kesempurnaan yang optimal dapat dicapai, maka berbagai potensi bawaan yang ada pada dirinya harus dikembangkan sedemikian rupa untuk mencapai kemampuan yang nyata dalam menjalani hidup dan kehidupan yang semestinya dalam suatu kepribadian yang utuh. Penjelasan tentang pengertian pendidikan karakter dan pendidikan akhlak di atas, dapat disimpulkan bahwa konsep dasar pendidikan karakter dalam pendidikan Islam berasal dari perkataan akhlaq bentuk jamak dari khuluq yang menurut bahasa diartikan budi pekerti, perangai, tingkah laku atau tabiat. Rumusan pengertian akhlak timbul sebagai media yang memungkinkan adanya hubungan baik antara Khaliq dan makhluk serta antara makhluk dan makhluk.

Pendidikan karakter mudah diterima di Indonesia, khususnya oleh para pemikir muslim, bukan karena konsep atau teori-teorinya yang baru, melainkan karena pendidikan karakter itu secara tersirat sebenarnya telah ada pada konsep pendidikan Islam yang selama ini telah diterapkan di Negara kita. Pendidikan karakter seolah-olah memperkuat sistem pendidikan Islam tersebut bahkan pantaslah jika pendidikan karakter itu merupakan ruh daripada pendidikan Islam. Pendidikan Islam pada hakikatnya kegiatan untuk membentuk anak didik menjadi manusia yang berkarakter atau bernilai, memiliki akhlak yang mulia sehingga menjadi manusia yang diridoi oleh Allah SWT. 
Pendidikan Islam bukanlah kegiatan tanpa tujuan yang jelas, bukanlah aktivitas dengan metode yang seadanya, bukan pula sistem yang dijalankan oleh orang yang tidak beradab. Layaknya pendidikan Islam, pendidikan karakterpun dengan teori-teori mutakhir diterima, dilaksanakan dan berada di tengah-tengah masyarakat muslim dengan objeknya adalah nak didik. Manusia yang membutuhkan bimbingan, pengajaran, pengetahuan, pertolongan dari manusia dewasa. Mereka haus dengan ilmu pengetahuan yang akan menerangi langkah-langkahnya di kemudian hari.

Karakter-karakter dasar yang dirumuskan baik oleh Indonesia Heritage Foundation antara lain: cinta kapada Allah dan semesta beserta isinya, tanggung jawab disiplin dan mandiri, jujur, hormat dan santun, kasih sayang, peduli, dan kerjasama, percaya diri, kreatif, kerja keras, dan pantang menyerah, keadilan dan kepemimpinan, baik dan rendah hati, toleransi, cinta damai, dan persatuan. Atau yang ditetapkan oleh Character Counts di Amerika seperti dapat dipercaya (trustworthiness), rasa hormat dan perhatian (respect), tanggung jawab (responsibility), jujur (fireness), peduli (caring),kewarganegaraan (citizenship), ketulusan (honesty), berani (courage), tekun (diligence), integritas. ${ }^{10}$ Bahkan seperti pemikiran yang disodorkan oleh Ginanjar dengan teori ESQ bahwa setiap karakter positif sesungguhnya akan merujuk kepada sifat-sifat mulia Allah, yaitu Asmaul Husna. Sifat sifat dan nama-nama mulia Tuhan inilah sumber inspirasi setiap karakter positif yang dirumuskan oleh siapapun dari sekian banyak karakter yang bisa diteladani dari nama-nama Allah, antara lain, jujur, tanggung jawab, disiplin, visioner, adil, peduli, dan kerjasama. ${ }^{11}$

Terlihat jelas nilai-nilai atau karakter-karakter yang harus dimiliki oleh anak didik selaras dengan tujuan bangsa Indonesia yang tertera dalam Undang-undang Republik Indonesia Nomor 20 tahun 2003 sebagai berikut: "Mengembangkan kemampuan dan membentuk watak serta peradaban bangsa yang bermartabat dalam rangka mencerdaskan kehidupan bangsa, yang bertujuan untuk berkembangnya potensi peserta didik agar menjadi manusia yang beriman dan bertaqwa kepada Tuhan Yang Maha Esa, berakhlaq mulia, sehat, berilmu, cakap, kreatif, mandiri, dan menjadi warga negara yang demokratis dan bertanggung jawab." Seorang Muslim juga harus membangun karakter mulia terhadap lingkungannya. Lingkungan yang dimaksud adalah

\footnotetext{
${ }^{10}$ Indonesia Heritage Foundation, Karakter-karakter Dasar, diambil Dari http://www.ihf.or.id pada tanggal 01 Januari 2017 pukul 12.00

${ }^{11}$ Ary Ginanjar Agustian, Rahasia Sukses Membangun Kecerdasan Emosi dan Spiritual ESQ, The ESQ Way 165, 1 Ikhsan 6 Rukun Iman 5 Rukun Islam, (Jakarta: Arga Publishing, 2009), h. 18
} 
segala sesuatu yang berada di sekitar manusia, yakni binatang, tumbuhan, dan alam sekitar (benda mati). Karakter yang dikembangkan adalah cerminan dari tugas kekhalifahan manusia di bumi, yakni untuk menjaga agar setiap proses pertumbuhan alam terus berjalan sesuai dengan fungsi ciptaan-Nya. Dalam Surat al-An'am (6): 38 dijelaskan bahwa binatang melata dan burung-burung adalah seperti manusia yang menurut al-Qurtubi tidak boleh dianiaya. ${ }^{12}$ Baik di masa perang apalagi ketika damai Islam menganjurkan agar tidak ada pengrusakan binatang dan tumbuhan kecuali terpaksa, tetapi sesuai dengan sunnatullah dari tujuan dan fungsi penciptaan (QS. AlHasyr [59]: 5).

Pembentukan manusia yang baik dalam pengetahuan, sikap, dan ketrampilan ini merujuk pada taksonomi Blomm. Bloom merumuskan tujuan pendidikan dengan dibagi menjadi beberapa domain (ranah, kawasan) dan setiap domain tersebut dibagi kembali ke dalam pembagian yang lebih rinci yaitu: (1) Cognitive domain (ranah kognitif), yang berisi perilaku-perilaku yang menekankan aspek intelektual; (2) Affective domain (ranah afektif) berisi perilaku-perilaku yang menekankan aspek perasaan dan emosi; dan (3) Psychomotor domain (ranah psikomotor) berisi perilaku-perilaku yang menekankan aspek keterampilan motorik. Beberapa istilah lain yang juga menggambarkan hal yang sama dengan ketiga domain tersebut di antaranya seperti yang diungkapkan oleh Dewantoro, yaitu: cipta, rasa, dan karsa.

Adapun istilah lain yang juga menggambarkan hal yang sama dengan ketiga domain di atas perspektif pendidikan Islam yaitu terintergrasinya antara iman, ilmu, dan amal. Domain ini merupakan dimensi yang harus bergerak saling melengkapi satu sama lain, sehingga mampu mewujudkan manusia sempurna (insan kamil). Perpaduan seluruh dimensi ini, telah menjadi idealisme yang sering digambarkan oleh ajaran Islam, seperti terinspirasikan dalam banyak ayat al-Qur’an yang menyertakan amal dan iman, serta tuntutan konsisten antara seruan yang disampaikan kepada orang lain dengan prilaku diri sendiri. Akhirnya berdasarkan penjelasan di atas dapat disimpulkan, hakikat perilaku yang berkarakter merupakan perwujudan totalitas psikologis yang mencakup seluruh potensi individu manusia (kognitif, afektif, dan psikomotorik) dan fungsi totalitas sosial-kultural dalam konteks interaksi (dengan Tuhan, diri sendiri, sesama manusia dan lingkungan) dan berlangsung sepanjang hayat. Penjabaran ini merupakan gambaran manusia kamil (sempurna) dalam pendidikan Islam.

\footnotetext{
${ }^{12}$ M. Quraish Shihab, Tafsir Al-Mishbah..., h. 270
} 


\section{Radikalisme di Indonesia}

Radikalisme adalah suatu perubahan sosial dengan jalan kekerasan, meyakinkan dengan satu tujuan yang dianggap benar tapi dengan menggunakan cara yang salah. Radikalisme dalam artian bahasa berarti paham atau aliran yang mengingikan perubahan atau pembaharuan sosial dan politik dengan cara kekerasan atau drastis. Namun, dalam artian lain, esensi radikalisme adalah konsep sikap jiwa dalam mengusung perubahan. Sementara itu radikalisme menurut pengertian lain adalah inti dari perubahan itu cenderung menggunakan kekerasan. Yang dimaksud dengan radikalisme adalah gerakan yang berpandangan kolot dan sering menggunakan kekerasan dalam mengajarkan keyakinan mereka. Sementara Islam merupakan agama kedamaian yang mengajarkan sikap berdamai dan mencari perdamaian Islam tidak pernah membenarkan praktek penggunaan kekerasan dalam menyebarkan agama, paham keagamaan serta paham politik.

Munculnya isu-isu politis mengenai radikalisme Islam merupakan tantangan baru bagi umat Islam untuk menjawabnya. Isu radikalisme Islam ini sebenarnya sudah lama mencuat di permukaan wacana internasional. Radikalisme Islam sebagai fenomena historis-sosiologis merupakan masalah yang banyak dibicarakan dalam wacana politik dan peradaban global akibat kekuatan media yang memiliki potensi besar dalam menciptakan persepsi masyarakat dunia. Banyak label-label yang diberikan oleh kalangan Eropa Barat dan Amerika Serikat untuk menyebut gerakan Islam radikal ini, mulai dari sebutan kelompok garis keras, ekstrimis, militan, Islam kanan, fundamentalisme, sampai terrorisme. Bahkan negara-negara Barat pascahancurnya ideologi komunisme (pasca perang dingin) memandang Islam sebagai sebuah gerakan peradaban yang menakutkan. ${ }^{13}$ Gerakan perlawanan rakyat Palestina, Revolusi Islam Iran, Partai FIS Al-Jazair, perilaku anti-AS yang dipertunjukkan Mu'ammar Khadafi ataupun Saddam Hussein, gerakan Islam di Mindanao Selatan, gerakan masyarakat Muslim Sudan yang anti-AS, merebaknya solidaritas Muslim Indonesia terhadap saudara-saudara yang tertindas, dan sebagainya adalah fenomena yang dijadikan media Barat dalam mengampanyekan label radikalisme Islam.

Dalam perspektif Barat, gerakan Islam sudah menjadi fenomena yang perlu dicurigai. Terlebih-lebih pasca hancurnya gedung WTC New York 11 September 2001

\footnotetext{
${ }^{13}$ Nurcholish Madjid, Pintu-Pintu Menuju Tuhan, (Jakarta: Paramadina, 1995), h. 270
} 
yang menurutnya dilakukan oleh kelompok Islam garis keras (Al-Qaeda dan Taliban), semakin menjadikan term radikalisme Islam lebih mengglobal yang berimplikasi pada sikap kecurigaan masyarakat dunia, terutama bangsa Barat dan Amerika Serikat, terhadap gerakan Islam. Hal yang demikian terjadi karena orang-orang Eropa Barat dan Amerika Serikat berhasil melibatkan diri dan mewarnai media sehingga mampu membentuk opini publik. Praktik-praktik kekerasan yang dilakukan sekelompok Islam dengan membawa simbol-simbol agama telah dimanfaatkan oleh orang-orang Barat dengan memanfaatkan media massa sebagai alat utama dalam memegang tampuk wacana peradaban, sehingga Islam terus menerus dipojokkan oleh publik.

Fenomena ini digambarkan dalam film Fitna dan penggambaran tentang kiamat. Namun, di titik yang berbeda ternyata agama (Islam) justru masuk dan merangsek menjarah wilayah publik. Barangkali masyarakat Barat telah tertipu oleh muslihat peradabannya sendiri dalam mengeksploitasi media yang diciptakannya. Islam merupakan agama kedamaian yang mengajarkan sikap berdamai dan mencari perdamaian. ${ }^{14}$ Sementara yang dimaksud dengan radikalisme adalah gerakan yang berpandangan kolot dan sering menggunakan kekerasan dalam mengajarkan keyakinan mereka. ${ }^{15}$ Islam tidak pernah membenarkan praktik penggunaan kekerasan dalam menyebarkan agama, paham keagamaan, serta paham politik. Tetapi memang tidak bisa dibantah bahwa dalam perjalanan sejarahnya terdapat kelompok-kelompok Islam tertentu yang menggunakan jalan kekerasan untuk mencapai tujuan politis atau mempertahankan paham keagamaannya secara kaku yang dalam bahasa peradaban global sering disebut kaum radikalisme Islam.

Praktik kekerasan (radikalisme) yang dilakukan oleh sekelompok umat Islam di Indonesia tidak dapat dialamatkan kepada Islam saja sehingga propaganda media Barat yang memojokkan Islam dan umat Islam secara umum tidak dapat diterima. Islam tidak mengajarkan radikalisme, tetapi perilaku kekerasan sekelompok umat Islam atas simbol-simbol Barat memang merupakan realitas historis-sosiologis yang dimanfaatkan media pers Barat untuk memberi label dan mengkampanyekan anti radikalisme Islam sosial-politik dan ekonomi supaya tidak terjadi kekerasan agama. Identitas keIslaman (kesadaran umum sebagai Muslim) memang menjadi identitas yang tepat dan referensi yang efektif bagi gerakan radikalisme. Tetapi faktor eksternal yaitu dominasi dan

\footnotetext{
${ }^{14}$ Ibid., h. 260

${ }^{15}$ Harun Nasution, Islam Rasional, (Bandung: Mizan, 1995), h. 124
} 
kesewenang-wenangan Barat atas negeri-negeri Muslim merupakan faktor yang lebih dominan yang memunculkan radikalisme Muslim sebagai reaksi.

Jadi jelas, bahwa radikalisme muncul dari kebanggaan (identitas keIslaman) yang terluka (oleh Barat), kekuatan media Barat dalam merepresentasi Islam, tekanan politik penguasa terhadap keberadaannya, emosi keagamaan, faktor kultural, tidak menerima perbedaan, ideologis anti westernisme, dan faktor kebijakan pemerintah. Solusi-solusi yang muncul harus dapat mencakup kompleksitas permasalahan yang kesemuanya harus berangkat dari kearifan para pemimpin Barat dan juga negeri-negeri Muslim untuk mampu membaca fenomena perkembangan zaman yang mencerminkan aspirasi dari kalangan Muslim. Di samping itu, perlu dipertimbangkan konsep penting religious revolution dan religion subcultures yang ditandai dengan adanya penghargaan terhadap pluralitas dan mendudukkan kondisiJika tidak, maka Islam yang damai akan termanifestasi dalam bentuk radikalisme yang penuh kekerasan.

Kekerasan bukanlah tipe agama-agama. Agama selalu menerapkan doktrin keselamatan dan kesejahteraan. Peter L. Berger sebagaimana dikutip Nur Syam, menawarkan dua konsep penting supaya tidak terjadi kekerasan agama, religious revolution, dan religion subcultures. ${ }^{16}$ Arahan pertama terkait dengan bagaimana elite agama dapat menumbuhkan dengan cepat kesadaran akan pentingnya model agama yang modern. Di dalam agama yang modern ditandai dengan adanya penghargaan terhadap pluralitas yang tidak vakum diversitas dan vakum budaya. Manusia hidup dalam entitas yang heterogen. Maka agama akan menjadi mode of comunication yang tidak hanya vertikal tetapi juga horizontal. Agama sebagai model komunikasi berarti menuntut kesepahaman dan mengakui perbedaan dalam banyak hal tetapi juga memiliki kesamaan misi kemanusiaan.

\section{E. Pendidikan Karakter Mencegah Tumbuhnya Radikalisme Agama}

Pengamalan terhadap nilai-nilai keagamaan di sekolah merupakan salah satu hal penting dalam mewujudkan sikap toleransi antar umat beragama, hal ini dikarenakan dengan adanya penanaman nilai-nilai tersebut maka akan dapat dikembangkan budaya toleransi beragama di sekolah. Selain hal tersebut, pendidikan karakter dalam kaitanya dengan nilai-nilai toleransi idealnya mampu mencegah semangat ekslusifisme yang ada

\footnotetext{
${ }^{16}$ Nur Syam, Bukan Dunia Berbeda: Sosiologi Komunitas Islam, (Surabaya: Eureka, 2005), h. 94
} 
di sekolah. Oleh karena itu, perlu upaya membangun kesadaran siswa tentang toleransi beragama di sekolah melalui pendidikan karakter. Di sini fungsi dan tanggung jawab guru tentu akan bertambah berat, karena guru harus memberikan penilaian yang tidak hanya sekedar berdasarkan hasil evaluasi, tetapi juga mengamati bagaimana perubahan perilaku siswa dalam bersosialisasi di lingkungan yang multikultur.

Pendidikan karakter merumuskan nilai-nilai yang harus dimiliki oleh anak didik setelah selesai mengikuti proses pembelajaran di dalam kelas. Nilai-nilai atau karakter yang harus dimiliki anak didik pada setiap pertemuan disesuaikan dengan materi pembelajaran pada saat itu. Pada hakikatnya dalam pendidikan Islampun nilai-nilai tersebut menjadi tujuan utama setelah kegiatan pembelajaran di dalam kelas dilakukan. Oleh karena itu, apa yang menjadi dasar pendidikan Islam merupakan dasar pijakan dalam penetapan konsep pendidikan karakter juga. Hal tersebut dilihat dari nilai-nilai atau karakter yang dirumuskan tidak bertentangan dengan dasar atau sumber pendidikan Islam yaitu al-Qur`an, al-Sunnah dan Ijtihad.

Karakter-karakter dasar yang dirumuskan baik oleh Indonesia Heritage Foundation antara lain: cinta kepada Allah dan semesta beserta isinya,tanggung jawab disiplin dan mandiri, jujur, hormat dan santun, kasih sayang, peduli, dan kerjasama, percaya diri, kreatif, kerja keras, dan pantang menyerah, keadilan dan kepemimpinan, baik dan rendah hati, toleransi, cinta damai, dan persatuan. ${ }^{17}$ Atau yang ditetapkan oleh Character Counts di Amerika seperti dapat dipercaya (trustworthiness), rasa hormat dan perhatian (respect), tanggung jawab (responsibility), jujur (fireness), peduli (caring),kewarganegaraan (citizenship), ketulusan (honesty), berani (courage), tekun (diligence), integritas.

Bahkan seperti pemikiran yang disodorkan oleh Ginanjar dengan teori ESQ bahwa setiap karakter positif sesungguhnya akan merujuk kepada sifat-sifat mulia Allah, yaitu Asmaul Husna. Sifat sifat dan nama-nama mulia Tuhan inilah sumber inspirasi setiap karakter positif yang dirumuskan oleh siapapun dari sekian banyak karakter yang bisa diteladani dari nama-nama Allah, antara lain, jujur, tanggung jawab, disiplin, visioner, adil, peduli, dan kerjasama. ${ }^{18}$ Terlihat jelas nilai-nilai atau karakterkarakter yang harus dimiliki oleh anak didik selaras dengan tujuan bangsa Indonesia yang tertera dalam Undang-undang Republik Indonesia Nomor 20 tahun 2003 sebagai

\footnotetext{
${ }^{17}$ Indonesia Heritage Foundation, Karakter...

${ }^{18}$ Ary Ginanjar Agustian, Rahasia Sukses...
} 
berikut: "Mengembangkan kemampuan dan membentuk watak serta peradaban bangsa yang bermartabat dalam rangka mencerdaskan kehidupan bangsa, yang bertujuan untuk berkembangnya potensi peserta didik agar menjadi manusia yang beriman dan bertaqwa kepada Tuhan Yang Maha Esa, berakhlaq mulia, sehat, berilmu, cakap, kreatif, mandiri, dan menjadi warga Negara yang demokratis dan bertanggung jawab."19

Serta sejalan dengan rumusan tujuan pendidikan Islam hasil kongres sedunia bahwa pendidikan harus ditujukan untuk menciptakan keseimbangan pertumbuhan kepribadian manusia secara menyeluruh, dengan cara melatih jiwa, akal fikiran, perasaan, dan fisik manusia. Dengan demikian, pendidikan harus mengupayakan tumbuhnya seluruh potensi manusia, baik yang bersifat spiritual, intelektual, daya khayal, fisik, ilmu pengetahuan, maupun bahasa, baik secara perorangan maupun kelompok, dan mendorong tumbuhnya seluruh aspek tersebut agar mencapai kebaikan dan kesempurnaan. Tujuan akhir pendidikan terletak pada terlaksananya pengabdian yang penuh kepada Allah, baik pada tingkat perseorangan, kelompok, maupun kemanusiaan dalam arti yang seluas-luasnya.

Pemuda adalah aset bangsa yang sangat berharga. Masa depan negeri ini bertumpu pada kualitas mereka. Namun ironisnya, kini tak sedikit kaum muda yang justru menjadi pelaku terorisme. Serangkaian aksi terorisme mulai dari Bom Bali-1, Bom Gereja Kepunton, bom di JW Marriot dan Hotel Ritz-Carlton,hingga aksi penembakan Pos Polisi Singosaren di Solo dan Bom di Beji dan Tambora, melibatkan pemuda. Sebut saja, Dani Dwi Permana, salah satu pelaku Bom di JW Marriot dan Hotel Ritz-Carlton, yang saat itu berusia 18 tahun dan baru lulus SMA. Fakta di atas diperkuat oleh riset yang dilakukan Lembaga Kajian Islam dan Perdamaian (LAKIP) dikutip dari Duta Damai (2017), dalam risetnya tentang radikalisme di kalangan siswa dan guru Pendidikan Agama Islam (PAI) di Jabodetabek, pada Oktober 2010-Januari 2011, LaKIP menemukan sedikitnya 48,9 persen siswa menyatakan bersedia terlibat dalam aksi kekerasan terkait dengan agama dan moral. ${ }^{20}$

Rentannya pemuda terhadap aksi kekerasan dan terorisme patut menjadi keprihatinan kita bersama. Banyak faktor yang menyebabkan para pemuda terseret ke

\footnotetext{
${ }^{19}$ Undang-Undang Republik Indonesia No 20 Tahun 2003 tentang Sistem Pendidikan Nasional, Jakarta: Pemerintah Republik Indonesia.

${ }^{20}$ Duta Damai, Membentengi Pemuda dari Radikalisme dan Terorisme, diambil dari website http://muda.dutadamai.id/membentengi-pemuda-dari-radikalisme-dan-terorisme/ pada tanggal 01 Januari 2017 pukul 12.00 .
} 
dalam tindakan terorisme, mulai dari kemiskinan, kurangnya pendidikan agama yang damai, gencarnya infiltrasi kelompok radikal, lemahnya semangat kebangsaan, kurangnya pendidikan kewarganegaraan, kurangnya keteladanan, dan tergerusnya nilai kearifan lokal oleh arus modernitas negatif.Untuk membentengi para pemuda dan masyarakat umum dari radikalisme dan terorisme, Badan Nasional Penanggulangan Terorisme- BNPT, menggunakan upaya pencegahan melalui kontra-radikalisasi (penangkalan ideologi). Hal ini dilakukan dengan membentuk Forum Koordinasi Pencegahan Terorisme (FKPT) di daerah, Pelatihan anti radikal-terorisme bagi ormas, Training of Trainer (ToT) bagi sivitas akademika perguruan tinggi, serta sosialiasi kontra radikal terorisme siswa SMA di empat provinsi. ada beberapa hal yang patut dikedepankan dalam pencegahan terorisme dan sikap radikalisme agama di kalangan pemuda, diantaranya adalah:

1. memperkuat pendidikan kewarganegaraan (civic education) dengan menanamkan pemahaman yang mendalam terhadap empat pilar kebangsaan, yaitu Pancasila, UUD 1945, NKRI, dan Bhineka Tunggal Ika. Melalui pendidikan kewarganegaraan, para pemuda didorong untuk menjunjung tinggi dan menginternalisasikan nilai-nilai luhur yang sejalan dengan kearifan lokal seperti toleransi antar- umat beragama, kebebasan yang bertanggungjawab, gotong royong, kejujuran, dan cinta tanah air sertakepedulian antar-warga masyarakat.

2. mengarahkan para pemuda pada beragam aktivitas yang berkualitas baik di bidang akademis, sosial, keagamaan, seni, budaya, maupun olahraga.

3. memberikan pemahaman agama yang damai dan toleran, sehingga pemuda tidak mudah terjebak pada arus ajaran radikalisme. Dalam hal ini, peran guru agama di lingkungan sekolah dan para pemuka agama di masyarakat sangat penting.

4. memberikan keteladanan kepada pemuda. Sebab, tanpa adanya keteladanan dari para penyelenggara negara, tokoh agama, serta tokoh masyarakat, maka upaya yang dilakukan akan sia-sia. ${ }^{21}$

\footnotetext{
${ }^{21}$ Badan Nasional Penanggulangan Terorisme-BNPT, Upaya Pencegahan Kontra-Radikalisasi (Penangkalan Ideologi), diambil dari website http://www.bnpt.go.id/ pada tanggal 01 Januari 2017 pukul 12.00 .
} 


\section{F. Penanaman Karakter Pendidikan Islam dalam Upaya Deradikalisasi Paham Radikal}

Ada tujuh karakter yang harus ditanamkan di dalam diri anak-anak, yaitu empati, hati nurani, kontrol diri, rasa hormat, kebaikan hati, toleransi, dan keadilan. Ketujuh macam kebajikan inilah yang dapat membentuk manusia berkualitas di mana pun dan kapan pun. Meskipun sasaran nya adalah anak-anak, namun bukan berarti tidak berlaku untuk orang dewasa. Dengan kata lain, tujuh kebajikan yang ditawarkan oleh Michele Borba ini berlaku untuk siapa pun dalam rangka membangun kecerdasan moralnya dan menumbuhkan karakter yang baik dalam rangka penanaman sikap deradikalsasi Agama. ${ }^{22}$

Empati merupakan inti emosi moral yang membantu anak memahami perasaan orang lain. Kebajikan ini membuatnya menjadi peka terhadap kebutuhan dan perasaan orang lain, mendorongnya menolong orang yang kesusahan atau kesakitan, serta menuntutnya memperlakukan orang dengan kasih sayang. Hati nurani adalah suara hati yang membantu anak memilih jalan yang benar daripada jalan yang salah serta tetap berada di jalur yang bermoral; membuat dirinya merasa bersalah ketika menyimpang dari jalur yang semestinya. Kontrol diri dapat membantu anak menahan dorongan dari dalam dirinya dan berpikir sebelum bertindak, sehingga ia melakukan hal yang benar, dan kecil kemungkinan mengambil tindakan yang berakibat buruk. Kebajikan ini membantu anak menjadi mandiri karena ia tahu bahwa dirinya bisa mengendalikan tindakannya sendiri. Sifat ini membangkitkan sikap mural dan baik hati karena ia mampu menyingkirkan keinginan memuaskan diri serta merangsang kesadaran mementingkan keperluan orang lain.

Rasa hormat mendorong anak bersikap baik dan menghormati orang lain. Kebajikan ini mengarahkannya memperlakukan orang lain sebagaimana ia ingin orang lain memperlakukan dirinya, sehingga mencegahnya bertindak kasar, tidak adil, dan bersikap memusuhi. Dengan ini ia akan memerhatikan hak-hak serta perasaan orang lain. Kebaikan hati membantu anak menunjukkan kepeduliannya terhadap kesejahteraan dan perasaan orang lain. Dengan mengembangkan kebajikan ini, ia lebih berbelas kasih terhadap orang lain dan tidak memikirkan diri sendiri, serta menyadari perbuatan baik sebagai tindakan yang benar. Toleransi membuat anak mampu menghargai perbedaan

\footnotetext{
${ }^{22}$ Michele Borba, Membangun Kecerdasan Moral: Tujuh Kebajikan Utama Agar Anak Bermoral Tinggi, Terj. Oleh Lina Jusuf, (Jakarta: PT. Gramedia Pustaka Utama, 2008), h. 7-8
} 
kualitas dalam diri orang lain, membuka diri terhadap pandangan dan keyakinan baru, dan menghargai orang lain tanpa membedakan suku, gender, penampilan, budaya, agama, kepercayaan, kemapuan, atau orientasi seksual. Dengan toleransi ia akan memperlakukan orang lain dengan baik dan penuh pengertian, menentang permusuhan, kekejaman, kefanatikan, serta menghargai orang-orang berdasarkan karakter merea.

Keadilan menuntun anak agar memperlakukan orang lain dengan baik, tidak memihak, dan adil, sehingga ia mematuhi aturan, mau bergiliran dan berbagi, serta mendengar semua pihak secara terbuka sebelum memberi penilaian apa pun. Ia juga terdorong untuk membela orang lain yang diperlakukan tidak adil dan menuntut agar setiap orang diperlakukan setara. ${ }^{23}$ Tujuh kebajikan itu menjadi pola dasar dalam membentuk karakter (akhlak) mulia dari sisi kemanusiaannya hingga sepanjang hidup ia akan menggunakannya. Untuk mendasari itu semua perlu terlebih dahulu diajarkan berbagai nilai kebajikan yang harus direalisasikan dalam perilaku nyata oleh setiap manusia dalam kehidupannya sehari-hari. Dengan demikian, seseorang akan mendapatkan kualitas sebagai insan kamil, insan yang berakhlak mulia, atau dengan istilah Michele Borba disebut manusia yang memiliki kecerdasan moral.

Dalam salah satu bukunya, 100 Ways to Enhance Values and Morality in Schools and Youth Settings, Kirschenbaum menguraikan 100 cara untuk bisa meningkatkan nilai dan moralitas (karakter/akhlak mulia) di sekolah yang bisa dikelompokkan ke dalam lima metode, yaitu: 1) inculcating values and morality (penanaman nilai-nilai dan moralitas); 2) modeling values and morality (pemodelan nilai-nilai dan moralitas); 3) facilitating values and morality (memfasilitasi nilai-nilai dan moralitas); 4) skills for value development and moral literacy (keterampilan untuk pengembangan nilai dan literasi moral; dan 5) developing a values educationprogram (mengembangkan program pendidikan nilai). ${ }^{24}$ Dari pendapat Kirschenbaum ini maka seorang pendidik harus merancang proses pendidikan yang berpedoman pada lima program tersebut. Pendidikan Islam jika dirancang dengan model Kirschenbaum tersebut, tentu akan semakin cepat membuahkan hasilnya. Para tokoh etika Islam mendasari pengembangan karakter manusia dengan fondasi teologis (akidah) yang benar, meskipun pemahaman teologi mereka berbeda-beda. Dengan fondasi teologis

\footnotetext{
${ }^{23}$ Ibid.

${ }^{24}$ Howard Kirschenbaum, 100 Ways to Enhance Values and Morality in School and Youth Settings, (Massachusetts: Allyn \& Bacon, 1995), h. 86
} 
itulah mereka membangun ide bagaimana seharusnya manusia dapat mencapai kesempurnaan agamanya sehingga menjadi orang yang benar-benar berkarakter mulia. Sedang para tokoh sekuler lebih menekankan para proses apa yang harus ditempuh oleh seseorang dalam rangka mencapai tujuan itu. Proses ini sama sekali mengabaikan landasan teologi (akidah).

Proses inilah yang sekarang banyak dikembangkan di lembaga-lembaga pendidikan baik formal, nonformal, maupun informal, karena hasilnya lebih mudah dan cepat terlihat. Namun, harus diakui ketiadaan fondasi teologis (akidah) tidak bisa menjamin untuk terwujudnya karakter mulia dalam diri seseorang yang sebenarnya, terutama dalam perspektif Islam. Karakter, dalam pandangan tokoh etika sekular, hanya terfokus pada hubungan manusia dengan sesamanya atau dengan alam sekitarnya, sementara dalam pandangan tokoh etika Islam karakter harus dimulai dengan membangun hubungan yang baik dengan Allah SWT. dan Rasulullah SAW., lalu berlanjut pada hubungan dengan sesamanya dan dengan lingkungannya.

\section{G. Penutup}

Ruang lingkup pendidikan Islam pada dasarnya mengacu kepada sumber-sumber yang berada dalam pedoman hidup umat Islam yaitu al-Qur`an, al-Sunnah, dan Ijtihad. Sehingga dalam keberadaannya di tengah-tengah masyarakat muslim tidak terlepas dari karakter-karakter atau nilai-nilai yang ada pada pedoman umat Islam tersebut. Karakterkarakter yang diharapkan telah dirumuskan secara jelas yang harus dimiliki oleh setiap anak didik setelah mereka menempuh pendidikan baik di lingkungan keluarga, lingkungan sekolah, maupun lingkungan masyarakat. Pendidikan karakter atau pendidikan watak muncul di Indonesia di tengah-tengah sistem pendidikan Islam yang diterima oleh masyarakat muslim dengan karakter-karakter yang dirumuskan sebagai penguat terhadap pendidikan Islam sehingga pendidikan karakter pada hakikatnya adalah ruh dalam pendidikan Islam.Indonesia adalah negara yang mayotitas penduduknya beragama Islam. Ada tujuh karakter pendidikan islam yang harus ditanamkan pada anak-anak dalam upaya deradikalisasi paham radikal yaitu empati, hati nurani, kontrol diri, rasa hormat, kebaikan hati, toleransi, dan keadilan. Jika umat Islam Indonesia memiliki karakter mulia ini, maka Indonesia telah berhasil membangun karakter bangsanya. Sebaliknya jika umat Islam Indonesia hanya bangga dalam hal kuantitas, tetapi tidak memperhatikan kualitas (terutama karakternya), maka Indonesia 
telah gagal membangun bangsanya. Artinya, ketika umat Islam benar-benar memahami ajaran agama Islam dengan baik mengamalkannya dalam kehidupan sehari-hari, pastilah terwujud tatanan kehidupan di tengah tengah masyarakat yang berkarakter dalam upaya deradikalisasi paham beragama dapat dimulai, baik elemen maupun akar radikalisme.

\section{H. Daftar Pustaka}

Al-Qur'an Tafsir (online), Diambil dari website http://tafsirq.com/59-al-hasyr/ayat-5 pada tanggal 01 Januari 2017 pukul 12.00.

Al-Qur'an Tafsir (online), Surat al-An'am (6), diambil dari website http://tafsirq.com/6Al-An'am/ayat-6 pada tanggal 01 Januari 2017 pukul 12.00.

Al-Qur'an Tafsir (online), Surat Al-Qalam Ayat 4, dikutip dari http://tafsirq.com/68-alqalam/ayat-4 pada tanggal 01 Januari 2017 pukul 12.00.

Al-Qur'an Tafsir (online), Surat Asy-Syams Ayat 8-10, diambil dari website http://tafsirq.com/91-asy-syams/ayat-8-10 pada tanggal 01 Januari 2017 pukul 12.00 .

Ary Ginanjar Agustian, Rahasia Sukses Membangun Kecerdasan Emosi dan Spiritual ESQ, The ESQ Way 165, 1 Ikhsan 6 Rukun Iman 5 Rukun Islam, Jakarta: Arga Publishing, 2009

Badan Nasional Penanggulangan Terorisme- BNPT, Upaya Pencegahan KontraRadikalisasi (Penangkalan Ideologi), diambil dari website http://www.bnpt.go.id/pada tanggal 01 Januari 2017 pukul 12.00.

D. H. Elkind, \& F. Sweet, You Are A Character Educator, Diambil Dari http://www.goodcharacter.com/Article 4.html pada tanggal 01 Januari 2017 pukul 12.00 .

Duta Damai, Membentengi Pemuda dari Radikalisme dan Terorisme, diambil dari websitehttp://muda.dutadamai.id/membentengi-pemuda-dari-radikalisme-danterorisme/pada tanggal 01 Januari 2017 pukul 12.00.

F. Mu'in, Pendidikan Karakter Konstruksi Teoritik dan Praktik, Yogyakarta: Ar-Ruzz Media, 2001

Harun Nasution, Islam Rasional, Bandung: Mizan, 1995

Heni Zuhriyah, Pendidikan Karakter (Studi Perbandingan Antara Konsep Doni Koesoema dan Ibnu Miskawaih), Surabaya: IAIN Sunan Ampel, 2010

Howard Kirschenbaum, 100 Ways to Enhance Values and Morality in Schools and Youth Settings, Massachusetts: Allyn \& Bacon, 1995

Indonesia Heritage Foundation, Karakter-karakter Dasar, diambil Dari http://www.ihf.or.id pada tanggal 01 Januari 2017 pukul 12.00.

Kamus Besar Bahasa Indonesia (online), Pengertian Akhlak, diambil Dari http://kbbi.web.id/akhlak pada tanggal 01 Januari 2017 pukul 12.00.

M. Quraish Shihab, Tafsir Al-Mishbah Pesan, Kesan dan Keserasian Al-Qur`an, Volume 13, Jakarta : Lentera Hati, 2002 
Michele Borba, Membangun Kecerdasan Moral: Tujuh Kebajikan Utama Agar Anak Bermoral Tinggi, Terj. Lina Jusuf, Jakarta: PT. Gramedia Pustaka Utama, 2008

Muslich, Mansur, Pendidikan Karakter Menjawab Tantangan Krisis, Jakarta: Bumi Aksara, 2011

Nur Syam, Bukan Dunia Berbeda: Sosiologi Komunitas Islam, Surabaya: Eureka, 2005

Nurcholish Madjid, Pintu-Pintu Menuju Tuhan. Jakarta: Paramadina, 1995.

Ratna Megawangi, Pendidikan Karakter Solusi yang Tepat untuk Membangun Bangsa, Bogor : Indonesia Heritage Foundation, 2004

Thomas Lickona, Educating for Character: How Our School Can Teach Respect and Responsibility. New York, Toronto, London, Sydney, Aucland: Bantam books, 1991

Ulil Amri Syarif, Pendidikan Karakter Berbasis Al-Qur'an, Jakarta: Raja Grafindo Press, 2012

Undang-Undang Republik Indonesia No 20 Tahun 2003 tentang Sistem Pendidikan Nasional, Jakarta: Pemerintah Republik Indonesia. 